\title{
Analytical description of the scattering of cellulose nanocrystals in tracheid wood cells. Corrigendum
}

\author{
Malte Ogurreck, ${ }^{*}$ Helga C. Lichtenegger‡ and Martin \\ Müller
}

Helmholtz-Zentrum Geesthacht, Zentrum für Material- und Küstenforschung $\mathrm{GmbH}$, Max-Planck-Strasse 1, 21502 Geesthacht, Germany. Correspondence e-mail:

malte.ogurreck@hzg.de

In the paper by Ogurreck \& Müller [J. Appl. Cryst. (2010), 43, 256-263], Helga Lichtenegger is missing from the list of authors. The complete list of authors should be M. Ogurreck, H. C. Lichtenegger and M. Müller.

\section{References}

Ogurreck, M. \& Müller, M. (2010). J. Appl. Cryst. 43, 256-263. 